\title{
Narrative between Action and Transformation: A. J. Greimas' narratological models
}

Rafael Duarte Oliveira Venancio ${ }^{1}$

\begin{abstract}
The French theorist A. J. Greimas, inspired by such studies, is considered one of the founders of Narratology through the construction of models of analysis where these invariables would be centered in the subject of the narrative and based on the action and the transformation of them. The objective of the present essay is to analyze the ideas of Greimas, as well as to look for the logical mechanism that resides in each model.
\end{abstract}

Keywords: Narratology, Narratives, Narrative action, Narrative transformation, Narrative subjects

The study of narratives found its founding moment with Russian Formalism and its study of folk and mythological narratives. Like the continental philosophy movement called structuralism, Russian formalism seeks invariables of the narrative and conditions common to all of them, whether past, present or even future.

The French theorist A. J. Greimas, inspired by such studies, is considered one of the founders of Narratology through the construction of models of analysis where these invariables would be centered in the subject of the narrative and based on the action and the transformation of them.

The objective of the present essay is to analyze the ideas of Greimas, as well as to look for the logical mechanism that resides in each model.

\section{Narratology and the subjects of the narrative}

What if we are talking about subjects, where the mobility of statements is greater? For A .J. Greimas (1977, p. 195), the place of this is in "discourse [which], considered at the level of its surface, thus appears as a syntagmatic unfolding dotted with polysemic

\footnotetext{
${ }^{1}$ Rafael Duarte Oliveira Venancio, $\mathrm{PhD}$, is professor at Universidade Federal de Uberlândia, Brazil.
} 
figures, charged with multiple virtualities, Continuous or diffuse discursive. "

But only a few figures of discourse, driven by their inclusion in actuarial roles, can be called 'actors' of this 'dynamic principle of contradictions' which is narrative. For Greimas (1977, p. 195), the actor is much more than the union between narrative and discursive structures, of the actuational and thematic roles, he is the "place of investment of these roles, but also of their transformation, because the semiotic, Which operates in the framework of narrative objects, consists essentially in the game of acquisitions and waste, substitutions and exchanges of values, modal or ideological. "

The set of these actors forms models, whose "mode of existence is that of the micro-universe described. But at the same time, they are more general than the particular contents and appear as invariants, as a type of organization of signification in microuniverses, of which the invested contents are nothing but variables. "(GREIMAS, 1973, pp. 223-224) .

The above mentioned models are so-called actuational models, and even having a linguistic origin, microuniverses can be traditional narratives, wonderful tales (as shown by V. Propp), divine mythologies As G. Dumézil shows us), plays (studied by E. Souriau) or even philosophical ideals and thoughts of homo loquens.

\section{Action in Narrative}

Now when Greimas (1973, pp. 225-226) is studying the description of each representative of a divine population by Dumezil, he works on a "hypothesis of an actuational model, seen as one of the possible principles of the organization of the semantic universe, excessively considerable to be apprehended in its entirety, In microuniverses accessible to man "(GREIMAS, 1973, page 227).

Greimas' actuational model is the result of his reflections on the works of Propp and Souriau. From the first, the notion is taken that "actors, who are classes of actors [...], have a metalinguistic status in relation to the actors; Presuppose, in addition, functional analysis, that is, the constitution of spheres" (GREIMAS, 1973, pp. 228-229). Thus, the wonderful Russian tale, as Propp establishes, is a articulation of seven characters: villain, donor (provider), helper, sought-for person (and its father), dispatcher, hero, and false hero. 
Thus, in reworking the types of roles proposed by Souriau and Propp, Greimas arrived at an actuational model, composed of six actuators: "the Subject (the Lion of Souriau and the hero of Propp), the Object (the Souriau's Sun and Propp's sought-for person), the Propeller (Souriau Scale and the dispatcher of Propp), the Recipient (Souriau's Land), Adjuvant (Souriau's Moon and Propp's helper and donor) and the Opponent (Mars of Souriau and villain and false hero of Propp)"(PRINCE, 2003, 1-2).

Moreover, taking into account the relations between the actors, Greimas (1973, pp. 235-236) draws the general structure of the actuarial model where "it is a whole founded entirely on the object of the subject's desire and situated as object of Communication, between the sender and the receiver, the subject's desire being, in turn, modulated in projections of the adjuvant and the opponent. "From these relations, Greimas himself sees the possibility of a graphic representation of the actuational model:

Figure 1: Actuational Model of A. J. Greimas

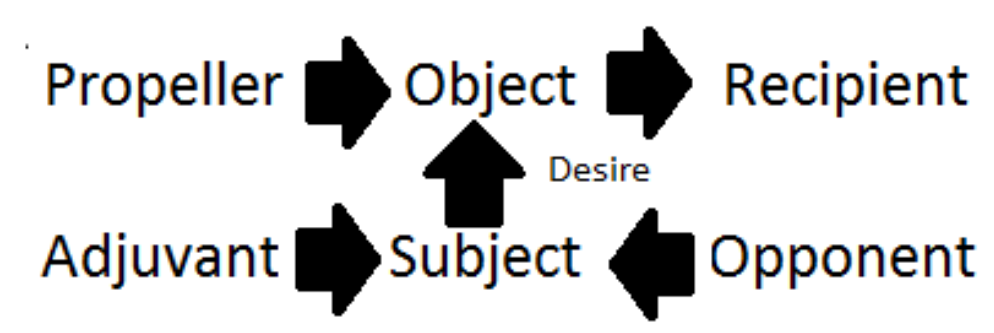

In this model (fig. 1), there is the possibility of a "thematic investiture", which is nothing more than a thematic force in the subject and object relation (represented graphically by the arrow) "carrying a heavier semic investiture, of 'desire', transforming itself in 'demand' "(GREIMAS, 1973, 236). Thus, this demand, driven by various thematic forces-ranging from basic human feelings (love, envy, jealousy) to political forces such as fanaticism, patriotism, and the desire for political life (GREIMAS, 1973, 237; (258259) - allows for the analysis of the already described situations of the "spectacle of knowledge" of the "philosopher of the classical epoch" with the sememic endowment of the "desire to know" and Marxist militancy with the semic endowment of " man".

In the first situation, the "Subject [is] the Philosopher himself; Object [is] the World; Destinator [is] God; Recipient [is] Humanity; Opponent [is] Matter; Adjuvant [is] 
Spirit. "(GREIMAS, 1973, p.236). In the second, the "Subject [is] Man; Object [is] Society without classes; Destinator [is] History; Recipient [is] Humanity; Opponent [is] bourgeois class; Adjuvant [is] Working class. "(GREIMAS, 1973, p.267).

With the examples above, it is easier to observe the other "axes" - Greimas calls them "categories" - of the actuational model and its relation to the central category, that of the desire between subject and object. On the upper axis, the sender and recipient, in Souriau's terms, is "frankly marked as the opposition between the Arbiter, assigner of the good, and the virtual Seeker of that Good." (GREIMAS, 1973, pp. 232-233).

That is, the subject takes the object - which is both the object of its desire as the object of communication between the sender and receiver - from the sender to the receiver. Thus the philosopher must seek the world in God to bring it to mankind, just as man must bring classless society from history to mankind.

Already in the lower "axis" - that is, in the adjunct versus opposing actuarial category -, there are two very distinct kinds of functions: "(1) The first [adjuvant], which consists in bringing help, acting in the sense of desire, or facilitating Communication; (2) and other [opponent], which, on the contrary, consist in creating obstacles, opposing both to the realization of desire and to the communication of the object "(GREIMAS, 1973, 233).

Thus, for the classical philosopher, spirit is its aid in the search for the World in God to bring it to humanity, while matter creates obstacles to avoid such action. The same can be said for Marxist militancy where the working class (proletariat) will help mankind in pursuit of classless society in history to bring it to humanity and that the bourgeois class is the opponent. We have, then, in the category of adjuvant versus opponents of the actuational model of Marxist militancy, the class struggle itself.

\section{Transformation in narrative}

However, Greimas believes that the actuarial model can be complemented with another model: the transformational one. After all, Dumézil's study demarcates two questions in the greimasian framework: "(a) what are the reciprocal relations and the common mode of existence of the agents of a microuniverse ?; (B) what is the very general meaning of the activity we attribute to the actors? In what does this 'activity' consist, and if it is transformative, what is the structural picture of these transformations? 
"(GREIMAS, 1973, 226).

The focus on this second question is the transformational model. It focuses on the narrative movement of the subject of the actantial model through the 31 proppian functions. They are: "(1) absence; (2) prohibition; (3) breach; (4) search; (5) information; (6) Disappointment; (7) submission; (8) villainy; (8a) foul; (9) command, order; (10) decision of the hero; (11) starting; (12) assignment of evidence; (13) confrontation of the test; (14) receiving the adjuvant; (15) special displacement; (16) combat; (17) signal; (18) victory; (19) dissolution of the fault; (20) return; (21) persecution; (22) release; (23) arrival incognita; (24) missing; (25) assigning a task; (26) success; (27) recognition; (28) disclosure of villainy; (29) revelation of the hero; (30) punishment; (31) marriage. (GREIMAS, 1973, pp. 252-253).

These 31 functions can be organized into four trajectory macrogroups: (a) The zero point (P0) of the subject, which comprises the absence (1) to villainy / fault (8 / 8a); (B) The point one (P1) of the subject, comprising the control, order (9) to victory (18); (C) The proof that P1>P0, which comprises dissolving the fault (19) to success (26); And (d) Point two (P2) of the subject, which comprises recognition (27) to marriage (31). Narrative ordering is that every story the subject starts from an obscure initial condition (P0) that is put to the test $(\mathrm{P} 1)$, needs to be recognized while conquered $(\mathrm{P} 1>\mathrm{P} 0)$ for the transformation of the subject by it (P2).

Thus, there is a dialectic development where $\mathrm{P} 0$ is the truth $(\mathrm{V})$ of the subject, $\mathrm{P} 1$ is the non-truth (NV) confronted, P1> P0 is the lie (M) that needs to fight and P2 is the non- Lie (NM) that needs to be positioned while narrative closure. Here is the principle of the transformational model.

For Greimas, the transformational model is a condition that sets up an equation where the result is "revealing a diachronic before and after." (GREIMAS, 1973, 330). It is composed of three moments: axiology, transformation and ideological choices.

Axiology is the assemblage of the incongruity of the dialectical development set down the path from $\mathrm{P} 0$ to $\mathrm{P} 2$. With this, the proportionality between positive and negative is put as approximate. Transformation is the resolution of axiology, demonstrating narrative links and ideological choices show the great narrative clash between two positions, truthful ideology (I1) and false ideology (I2). The equation of the transformational model is as follows: 
Figure 2: Transformational model of A. J. Greimas

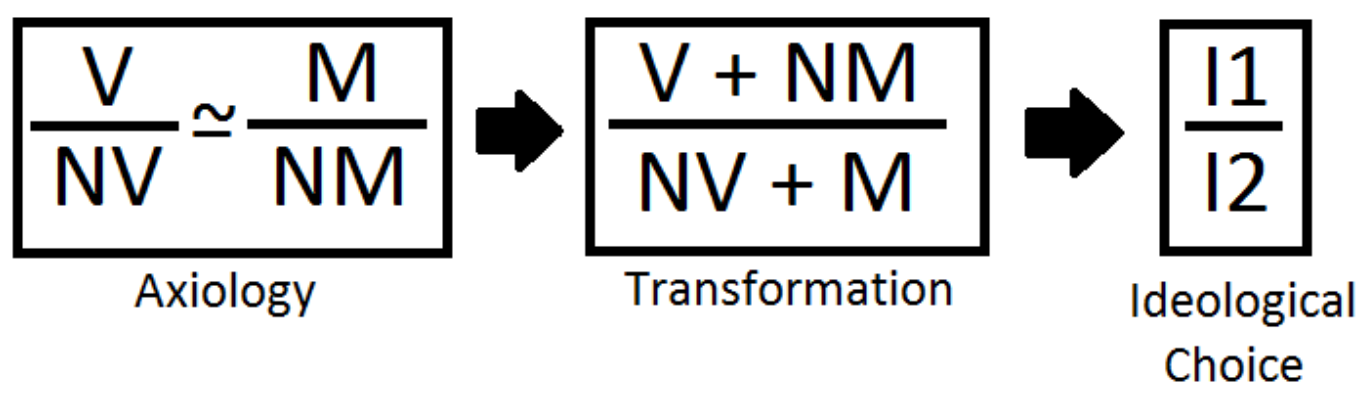

Thus, Greimas states that every subject has a hidden truth at the beginning of the narrative (V) that ends up being replaced by the non-truth (NV) soon after the villainy or initial fault. To this non-truth, a lie is added (M) composing a false ideology (I2). Thus, only with success can the hero, together with non-lie (NM) rescue his truth, as well as his true ideology (I1). In short, every hero, in the beginning, is only a half of I1, and only with the confrontation of a condition I 2 and his success against it, can he reveal his ideological wholeness.

Along with the actuational model, analysis of narrative diegenesis, the transformational model, subject's ideology, complete the form of structural analysis that Greimas proposes to us.

\section{References}

GREIMAS, A. J. Semântica Estrutural. São Paulo: Cultrix/Edusp, 1973.

GREIMAS, A. J. "Os atuantes, os atores e as figuras". In: Semiótica Narrativa e Textual. São Paulo: Cultrix/Edusp, 1977, p. 179-195.

PRINCE, G. A dictionary of narratology. Lincoln: U. Nebraska Press, 2003.

SOURIAU, E. Les Deux Cent Mille Situations dramatiques. Paris: Flammarion, 1950. 